\title{
Molecular Pathogenetics of Renal Cancer
}

\author{
Andreas A. Skolarikos Athanasios G. Papatsoris Gerasimos Alivizatos \\ Charalambos Deliveliotis
}

Athens Medical School, 2nd Department of Urology, Sismanoglio Hospital, Athens, Greece

\section{Key Words}

Renal cancer $\cdot$ Genetics $\cdot$ Molecular biology

\begin{abstract}
Recent developments in genetics and molecular biology have led to an increased understanding of the pathobiology of renal cancer. Thorough knowledge of the molecular pathways associated with renal cancer is a prerequisite for novel potential therapeutic interventions. Studies are ongoing to evaluate novel anticancer agents that target specific molecular entities. This article reviews current knowledge on the genetics and molecular pathogenesis of sporadic and inherited forms of renal cancer.

Copyright $\odot 2006$ S. Karger AG, Basel
\end{abstract}

\section{Introduction}

Renal cancer is comprised of several different types of cancer, each with a different histology, clinical course, and genetic background (table 1) [1]. For these different tumor types, hereditary, familial and sporadic forms exist. Most of our current knowledge was originally derived from studies on familial forms of the disease, but subsequent studies of sporadic cancers found similar changes (table 2) [2].

Renal cell carcinoma (RCC) is increasing in frequency in the United States and is often detected late in the course of disease due to nonspecific symptoms [3]. Understanding of the molecular alterations in patients with familial and sporadic renal tumors might provide some insight into the underlying mechanisms of RCC initiation and progression, which will be reviewed separately for sporadic and inherited forms.

\section{Sporadic RCC}

\section{Clear-Cell RCCs}

The von-Hippel-Lindau (VHL) Tumor Suppressor

Gene

Clear-cell RCCs are characterized by a non-homologous chromatid exchange leading to loss of genetic material from the short (p) arm of chromosome 3 and gains of material to the long (q) arm of chromosome 5 [4]. Loss of heterozygosity $(\mathrm{LOH})$ studies in sporadic RCCs identified three common regions of allelic loss: 3p12-14 [5], $3 p 21-22$ [6], and 3p25-26 [7].

Loss of $3 p$ and gain of $5 q$ implicate genes within these regions as being involved in clear-cell RCC tumorigenesis. Tumor-suppressor genes are likely to be found in areas of chromosomal loss (3p), while oncogenes are usually found in areas of chromosomal gain (5q). The only gene definitively shown to be involved in the development of such tumors is the tumor suppressor von-HippelLindau (VHL) gene, located at 3p25 [7, 8]. Renal cell can-

\section{KARGER \\ Fax +41613061234 \\ E-Mail karger@karger.ch}

www.karger.com (c) 2006 S. Karger AG, Basel

$0250-8095 / 06 / 0263-0218 \$ 23.50 / 0$

Accessible online at:

www.karger.com/ajn
Andreas A. Skolarikos MD, PhD, FEBU

Athens Medical School, 2nd Department of Urology

Sismanoglio General Hospital, 6, Laskareos St, Nea Zoi, Peristeri

GR-12137 Athens (Greece)

Tel. +30 210578 2291, Fax +30 210532 1303, E-Mail andskol@yahoo.com 
Table 1. Cytogenetic features of RCC

\begin{tabular}{lllll}
\hline Tumor & Site of origin & Genes & $\begin{array}{l}\text { Numerical chromosomal } \\
\text { abnormalities }\end{array}$ & $\begin{array}{l}\text { Chromosomal } \\
\text { translocations }\end{array}$ \\
\hline $\begin{array}{llll}\text { Clear-cell RCC } \\
\text { Papillary RCC }\end{array}$ & $\begin{array}{l}\text { Proximal renal tubule } \\
\text { Proximal renal tubule }\end{array}$ & $\begin{array}{l}\text { VHL, BHD, RASSFIA, FHIT } \\
\text { c-MET, FH, TFE3, PRCC, RCC 17 }\end{array}$ & $\begin{array}{l}-3 \mathrm{p},+5 \mathrm{q},-\mathrm{Y},-8 \mathrm{p},-9 \mathrm{p},-14 \mathrm{q} \\
+7,+17,-\mathrm{Y},+12,+16,+20\end{array}$ & $\begin{array}{l}\mathrm{t}(3 ; 5)(\mathrm{p} ; \mathrm{q}) \\
\mathrm{t}(\mathrm{X} ; 1)(\mathrm{p} 11.2 ; \mathrm{q} 21.2) \mathrm{t}(\mathrm{X} ; 17) \\
(\mathrm{p} 11.2 ; \mathrm{q} 25.3)\end{array}$ \\
Chromophobe RCC & $\begin{array}{l}\text { Intercalated cell of renal } \\
\text { Collecting duct }\end{array}$ & BHD & $-1,-2,-6,-10,-13,-17,-21$ & Unknown \\
Collecting duct RCC & Renal collecting duct & Unknown & $-1 \mathrm{q} 32,-6 \mathrm{p},-8 \mathrm{p},-21 \mathrm{q}$ & Unknown \\
\hline
\end{tabular}

Table 2. Inherited forms of RCC

\begin{tabular}{|c|c|c|c|c|c|}
\hline & Gene & Location & Protein & Function & Histology \\
\hline Von Hippel-Lindau disease & VHL & 3 p25 & pVHL & Tumor suppressor & Clear cell RCC \\
\hline Hereditary papillary renal cancer & cMET & $7 \mathrm{q} 31$ & $\begin{array}{l}\text { Hepatocyte growth } \\
\text { factor receptor }\end{array}$ & Oncogene & Type-1 papillary RCC \\
\hline Hereditary leiomyomatosis renal cancer & $\mathrm{FH}$ & $1 q 42-43$ & Fumarate hydratase & Tumor suppressor & Type-2 papillary RCC \\
\hline Birt-Hogg-Dubé syndrome & BHD & $17 \mathrm{p} 11.2$ & Folliculin & Tumor suppressor & Chromophobe RCC, oncocytoma \\
\hline
\end{tabular}

cers found in VHL follow Knudson's theory of the two-hit model of carcinogenesis [7]. The VHL gene is inactivated in patients with VHL and in almost $100 \%$ of sporadic clear-cell RCC $[8,9]$.

To evaluate whether inactivation of the VHL gene is essential for tumor formation, the patterns and extent of allelic losses on $3 p$ were compared in a set of conventional RCCs with and without VHL mutations. Although the frequency of 3p12-22 LOH was similar in both tumor types, $\mathrm{LOH}$ at $3 \mathrm{p} 25-26$ was significantly less frequent than $\mathrm{LOH}$ at 3p12-22 in tumors without VHL mutation, whereas LOH at 3p25-26 and 3p12-22 was similar in tumors with or without VHL mutation [10-12]. These results support the presence of both VHL-dependent and VHL-independent carcinogenic pathways, and indicate that inactivation of a tumor-suppressor gene at 3p12-22 might play an important role in both these pathways.

The inactivation of VHL is possible by mutation, deletion, or methylation. Mutations of the VHL gene seen in sporadic RCC differ from those seen in RCC associated with VHL disease. In sporadic RCC, $45 \%$ of the mutations are clustered in the second exon, although abnormalities are seen in all three exons. Large deletions are not observed, and $48 \%$ of the mutations are micro-deletions or insertions, resulting in frame shifts of the protein-coding sequence [9]. The role of the VHL protein in carcinogenesis will be discussed in the section of inherited RCC.
Other Tumor Candidate Genes in the 3p Region

Apart from the locus in 3p25-26, other loci on the $3 \mathrm{p}$ chromosome, such as $3 \mathrm{p} 12$, 3p14.2, 3p21.1, 3p21.3, 3 p22 and 3p26.2, might be involved in clear-cell RCC initiation or progression, and tumor-suppressor genes at these loci are inactivated. Non-papillary renal carcinoma-1 (NRC-1) and non-papillary renal carcinoma-2 (NRC-2) genes located in 3p12 and 3p14.2 regions, respectively, have also been related to RCC $[13,14]$. Within the NRC-2 region, the tumor-suppressive region was further narrowed down to a genomic segment which contains both exons 9 and 10 of the fragile histidine triad gene (FHIT) [14].

Tumor-suppressive activity within the NRC-1 region was also observed in VHL-defective RCC cell lines, and it was hypothesized that NRC-1 might act either downstream from VHL within the same pathway or act in a pathway not related to VHL [15]. Moreover, a function in apoptosis has been suggested, but the exact role of NRC-1 in RCC awaits the identification of further candidate genes in this region.

The 'down-regulated in RCC' gene (DRR1) has been identified in the chromosomal 3p21.1 region. A reduced expression of this gene in clear-cell RCCs, and growth suppression after transfection of DRR1-negative cell lines with wild-type DRR1, support a role for this gene in RCC development [16]. 
Hypermethylation and subsequent silencing of RASSF1A, a tumor-suppressor gene located in the $3 \mathrm{p} 21.3$ region, has been demonstrated in clear-cell RCCs [17]. RASSF1A shows significant homology to the mouse RAS protein Norel and to the rat protein Maxpl, both interacting with RAS in a GTP-dependent manner [18]. The presence of conserved domains in the RASSF1A protein, known to play important roles in several signal transduction pathways, supports a role for RASSF1A in RAS signaling [18]. As such, inactivation of the RASSF1A gene might have the same cellular effect as oncogenic RAS mutations [18].

Transforming growth factor- $\beta$ (TGF- $\beta$ ) is a potent inhibitor of epithelial cell growth. By binding to the TGF- $\beta$ receptor complex, consisting of type I (T $\beta R-I)$ and type II (T $\beta R$-II) receptors, its biological activity is exerted. The gene for the T $\beta R$-II has been mapped to chromosome 3 p22. Alterations in T $\beta R-I I$ make epithelial tumors insensitive to the inhibitory effects of TGF- $\beta$ and are correlated with malignant progression [19]. Rescue of wildtype T $\beta$ R-II activity by gene transfection restored TGF- $\beta$ responsiveness and reduced the growth rate in different subtypes of human RCC and in a mouse RCC cell line [20, $21]$, suggesting a role for T $\beta R$-II and the TGF- $\beta$-regulated pathway in RCC development [19]. Further support for such a role was demonstrated through altered expression of proteins downstream in the TGF- $\beta$-signaling pathway, such as SMAD2 and SMAD4 [22]. Significant elevations of plasma TGF- $\beta$ levels have been recorded in patients with RCC [23].

Another candidate gene, located on $3 \mathrm{p} 26.2$, is the 8-oxoguanine DNA glycosylase gene (OGG1) involved in DNA repair. LOH for this gene was found in $85 \%$ of conventional RCCs, while an inactivating mutation was also reported [24].

Based on the frequent loss of chromosome 3 sequences in conventional RCCs, the chromosome 3 candidate genes discussed above are suggested to be specific for this subtype of RCC. However, silencing of the RASSF1A gene by promoter hypermethylation has also been detected in papillary RCCs, and genetic alterations in the T $\beta R$-II gene have been found in other RCC subtypes [25]. In addition, VHL and FHIT locus loss was demonstrated in all RCC subtypes, but differed in pattern and prognostic significance [25]. Thus, there are overlaps in these carcinogenic pathways between the different RCC subtypes.

\section{Tumor Candidate Genes in Other Regions}

No specific proto-oncogenes from $5 q$ have been found mutated in clear-cell RCC [26]. With advancing grade and stage, clear-cell RCCs exhibit the loss of a variety of stereotypical chromosomal regions, most commonly in $8 p, 9 p, 14 q, 6 q$ and $17 p$ chromosomes [27].

RCC rarely acquires mutations in the p53 tumor-suppressor gene, suggesting that p53 signaling might be repressed by some other mechanism [28]. In RCC cells, p53 undergoes all expected conversions in response to DNA damage but paradoxically does not induce transactivation [28]. This situation can be explained either by a lack of some $\mathrm{p} 53$ counterpart that is essential for transactivation or by the presence of an inhibitor of transactivation [28]. There is a detectable repression of p 53 transactivation in normal kidney cells that is also dominant in cell fusion experiments, indicating that RCC cells may use an existing kidney-specific mechanism of $\mathrm{p} 53$ attenuation to achieve complete inhibition of the p53 pathway [28].

Abnormalities of other tumor-suppressor genes, such as the RB gene, MCC and APC genes, WT1 gene and $\mathrm{nm} 23$ gene, have been implicated in sporadic RCC [29].

\section{Oncogenes and Growth Factors in Sporadic RCC}

A number of oncogenes have been evaluated in sporadic RCCs. The ras family has been extensively evaluated but does not appear to be critical in RCC [30]. Conflicting results have been reported concerning the expression of HER-2/neu in RCC with most investigators showing a low expression [31]. Abnormal expression of the myc and fas oncogenes has also been reported in renal carcinomas with significant elevation in $50-90 \%$ of sporadic renal cancers $[32,33]$. Other oncogenes, such as $\mathrm{abl}_{\mathrm{r}}$, fes, fms, myb, src, and raf, are not expressed or are expressed infrequently in RCC [33].

Activation of several growth factors might be important in the pathogenesis of RCC. Epidermal grow th factor (EGF), a potent mitogen, stimulates cultures of RCC cell lines [34]. However, most investigators have not detected EGF in tumor tissue from patients with RCC [35]. Overexpression of the EGF receptor has been reported by several authors [35-37]. Elevated levels of transforming growth factor- $\alpha$ (TGF- $\alpha$ ) have been observed in VHLdeficient cancer cells [38]. TGF- $\alpha$ acts as growth-stimulating factor and induces the expression of the EGF receptor. Blockage of this receptor by a monoclonal antibody inhibits the growth of RCC cell lines cultured with TGF$\alpha$ [36]. TGF- $\alpha$ acts synergistically with TGF- $\beta$ in inducing transformation and, as such, they are both involved in RCC-related pathways [38].

Other growth factors might also play a role in the initiation or progression of RCC. Truncated fibronectin is secreted by the ACHN RCC cell line and stimulates DNA 
synthesis in the absence of other growth factors [39]. Hepatocyte growth factor appears to stimulate proliferation in some RCC cell lines [40]. Other RCC cell lines appear to secrete an autocrine growth promoter when cultured in the presence of 5 -fluorouracil [41]. This growth factor potentiated the effects of EGF, TGF- $\beta$, and other mitogens. Sera from patients with end-stage renal disease stimulate proliferation of RCC cell lines, and the uncharacterized growth factor implicated in this proliferation does not appear to be EGF, basic fibroblast growth factor (bFGF), or platelet-derived growth factor (PDGF) [42].

\section{Papillary RCC}

Papillary RCCs (PRCCs) are suggested to be of renal proximal tubular origin and two histological subtypes exist, classified as type I and type II [43, 44]. Type-I PRCC is less frequent, it is associated with c-MET mutations, and is seen in the hereditary papillary renal cancer syndrome and occasional sporadic PRCC (with or without MET mutations) [44]. Type-II PRCC does not harbor cMET mutations and is the type most commonly encountered sporadically [45].

A combination of gains of chromosomes 7 and 17 and loss of the Y have been found in PRCCs [46-48]. A relative gain of chromosome $3,3 \mathrm{q}$ material, or both has occasionally been found, although not in the setting of detectable VHL gene mutations [46-48]. There are also reports regarding gains at chromosomes 16 and 20, especially in advanced stages of PRCC [46-48] and chromosomal losses of 1p, 6q, 9p [46, 47].

A rare subset of PRCCs contains losses of the short arm of the X chromosome that are associated with translocations to various chromosomes including $\mathrm{T}(\mathrm{X} ; 1)(\mathrm{p} 11$; q21), which have repeatedly been encountered [49]. Positional cloning of the translocation breakpoint revealed an in-frame fusion of the TFE3 gene on the $\mathrm{X}$ chromosome to a novel gene, PRCC, on chromosome $1[49,50]$. TFE3 is a ubiquitously expressed transcription factor belonging to the family of E-box binding factors [51].

The PRCC protein is an ubiquitously expressed nuclear protein characterized by a relatively high proline content, without homology to any other known protein [50, 52]. The in-frame fusion results in two fusion genes, the TFE3PRCC and the PRCCTFE3, which are both expressed in $\mathrm{t}(\mathrm{X} ; 1)$-positive tumor cells [50]. The fusion protein PRCCTFE3 retains all the domains of TFE3 necessary for transcriptional activation. The PRCC protein interacts with MAD2B, a human homologue of the yeast
MAD-family protein Mad2, a component of the mitotic spindle checkpoint [53]. Mitotic checkpoint proteins have been shown to be essential for delaying the onset of anaphase and thus preventing mis-segregation of chromosomes during metaphase $[54,55]$. Recently, the MAD2B protein has been found to bind indirectly to the anaphase-promoting complex (APC) [56] and to act as an inhibitor of Cdh1-mediated activation of APC $[54,57]$. There is evidence suggesting that expression of PRCC/ TFE3 leads to impairment of mitotic checkpoint control through interference with MAD2B binding and thus, in a dominant-negative fashion, to papillary RCC development [25].

Cytogenetic studies revealed variant translocations in which TFE3 is fused to other genes such as RCC17 on chromosome 17, PSF on chromosome 1, and NonO $\left(\mathrm{p} 54^{\mathrm{nrb}}\right)$ on chromosome X $[49,58]$. As PSF and NonO $\left(\mathrm{p} 54^{\mathrm{nrb}}\right)$ both encode pre-mRNA splicing factors, a similar role was suggested for PRCC [59]. Although activating mutations of the MET proto-oncogene, which encodes the hepatocyte growth factor receptor, are common in families with hereditary papillary renal cancer, only a few sporadic PRCCs are found to have MET mutations [60]. Nevertheless, two- to threefold gains in chromosome 7 or the $7 \mathrm{q} 31$ location of the MET proto-oncogene have been demonstrated in sporadic PRCC $[48,61]$. Gains of chromosome 7q harboring a wild-type MET may be carcinogenic by virtue of increased gene copy number and perhaps increased cellular responsiveness to hepatocyte growth factor. The relative paucity of MET mutations found in sporadic papillary tumors may be explained by the fact that gains of wild-type MET copy number may be sufficient for tumorigenesis [61].

\section{Chromophobe RCC}

Chromophobe RCCs (CRCCs) arise from the intercalated cells of the cortical collecting ducts [62]. Cytogenetically, the CRCC shows widespread LOH of chromosomes 1, 2, 6, 10, 13, 17 and 21 and hypodiploidy due to non-random multiple chromosome losses [63]. The loss of chromosome $\mathrm{Y}$ in tumors from male patients has also been recorded [43]. Allelic changes in 3p have also been described, but these results could be explained by the tendency for loss of the entire chromosomes of these specific RCCs [64]. These multiple losses have made it challenging to define specific genes essential to the development of CRCC. 
The p53 tumor-suppressor gene has been implicated based on the common finding of chromosome 17 loss, $17 \mathrm{p} \mathrm{LOH}$, and the detection of p53 mutations in 30\% of these tumors [65]. The recently cloned gene for the BirtHogg-Dubé syndrome may shed light on CRCC, because CRCCs have been found at increased frequency in patients with this syndrome [66].

\section{Collecting Duct Carcinoma}

The collecting duct carcinoma is a rare tumor which is derived from the collecting duct epithelia [62]. Data regarding the cytogenetic abnormalities of collecting duct carcinoma are scarce. Conflicting findings have been reported, with some studies detecting monosomies and others reporting trisomies.

Three collecting duct cancers have been characterized cytogenetically. Each cancer was consistently monosomic for chromosomes $1,6,14,15$, and 22 [67]. $\mathrm{LOH}$ at $1 \mathrm{q} 32.1-32.2,6 \mathrm{p}, 8 \mathrm{p}$, and 21q was subsequently reported in a larger series [67-69]. Gains at chromosomes 16 and 20 and losses at 1,2, 9, 11, and 18 have also been revealed [68]. Trisomy 17, trisomy or tetrasomy 7 , or deletion of chromosome $3 p$ were not observed by cytogenetic analysis, differentiating these tumors from papillary and clearcell RCC, respectively [69].

\section{Inherited RCC Biochemical Pathways}

There are four types of inherited epithelial kidney cancer in which the responsible genes have been identified (table 2): (a) VHL clear-cell RCC, (b) hereditary papillary renal carcinoma (HPRC), which mainly refers to type-1 papillary renal carcinoma, (c) hereditary leiomyomatosis RCC (HLRCC), where type-2 papillary renal carcinoma and other carcinomas are included, and (d) the Birt-Hogg-Dubé (BHD) syndrome, where chromophobe renal carcinoma and oncocytoma predominate.

\section{VHL Clear-Cell RCC}

Patients with VHL disease are at significant risk for the development of early onset, bilateral, multi-focal renal tumors, and renal cysts [70]. Genetic linkage analysis of the VHL families revealed the VHL tumor-suppressor gene on the short arm of chromosome 3 at the 3 p 25 region $[70,71]$. In hereditary cancers, patients inherit one defec-

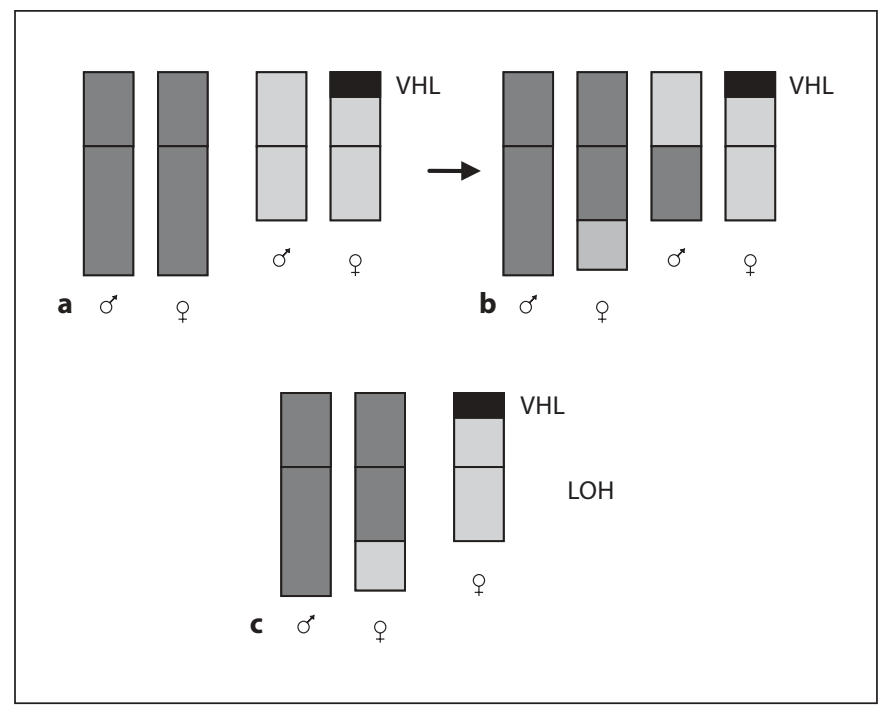

Fig. 1. The two 'hit' hypothesis of carcinogenesis in VHL disease. a Patients inherit a mutated VHL allele as a first 'hit' (black bar). b In kidney cells a balanced chromosomal translocation occurs. c Loss of heterozygosity (LOS) by losing one paternal allele is the second 'hit' of carcinogenesis.

tive tumor-suppressor gene from one parent in every cell (one 'hit') but no tumors occur until their remaining allele becomes mutated or deleted (i.e. somatic loss, a second 'hit', the Knudsen hypothesis; fig. 1). This two-hit hypothesis is supported by the finding that all patients with VHL syndrome have been found to harbor a germline VHL gene that is either mutant or partially or completely deleted [72]. Cells from the clear-cell RCCs of VHL patients have also lost their normal unaffected copy of VHL [73]. Because patients with familial cancers such as VHL clear-cell RCC inherit a germline mutation, they only require one hit to inactivate the remaining tumorsuppressor gene. Patients with sporadic tumors require two hits, which occur less frequently [74].

VHL syndrome demonstrates considerable phenotypic diversity and not all germline VHL mutations are associated with a risk of RCC development [70]. There is a marked genotype-phenotype correlation between VHL gene mutations and manifestations of the different phenotypes. Based on these differences, VHL families have been divided into two major subgroups: VHL types 1 and $2[75,76]$. VHL type 1 represents the most common group, and is characterized by a predisposition to develop retinal angiomas, central nervous hemangioblastomas, and conventional RCCs. VHL type 2 is subdivided into type $2 \mathrm{~A}$ and $2 \mathrm{~B}$. VHL type $2 \mathrm{~A}$ is the next most common 
Fig. 2. Hypoxia-inducible pathways. Signaling starts with the interaction of growth factors with several tyrosine kinase cell surface receptors. The phosphatidylinositol 4,5-bisphosphate-AKT-mammalian target of the rapamycin pathway (P13KAKT-mTOR) and the Ras/Raf/MEK/mitogen-activated protein kinase (MAPK) pathway are activated. VHL protein complexes with elongin B, elongin C, Cullin2, and Rbxl and forms a ubiquitin ligase. In the presence of oxygen, VHL recognizes hydroxylated proline residues on HIF- $\alpha$ and binds them. Once bound, HIF becomes ubiquinated and tagged for proteosome-dependent protein degradation. In the absence of oxygen or with loss of PVHL function, HIF- $\alpha$ is allowed to accumulate, ultimately binding to HIF- $\beta$ and resulting in increased expression of hypoxia-inducible genes. The later encode proteins essential to cancer cell functions under hypoxia, such as glucose transport, angiogenesis, glycolysis, cell growth, migration and $\mathrm{pH}$ control. Inhibition of this pathway by small molecules targeted against various steps should at least partly reverse the molecular consequences of VHL loss of function and result in anticancer effects (shown as grey-shaded arrows and boxes). $\mathrm{EGFR}=$ Epidermal growth factor receptor; VEGFR = vascular endothelial growth factor receptor; IGFR = insulin growth factor receptor; $\mathrm{MEK}=$ mitogen-activated protein (extracellular signal regulated kinase); HIF = hypoxia-inducible factor; $\mathrm{FIT}=$ fanesyl transferase inhibitors; $\mathrm{VBC}=$ ubiquitin ligase complex; Hsp90 = heat shock protein-90; TGF = transforming growth factor; CAIX = carbonic anhydrase IX; CXCR4 = chemokine receptor 4; Glut-1 = glucose transporter-1.

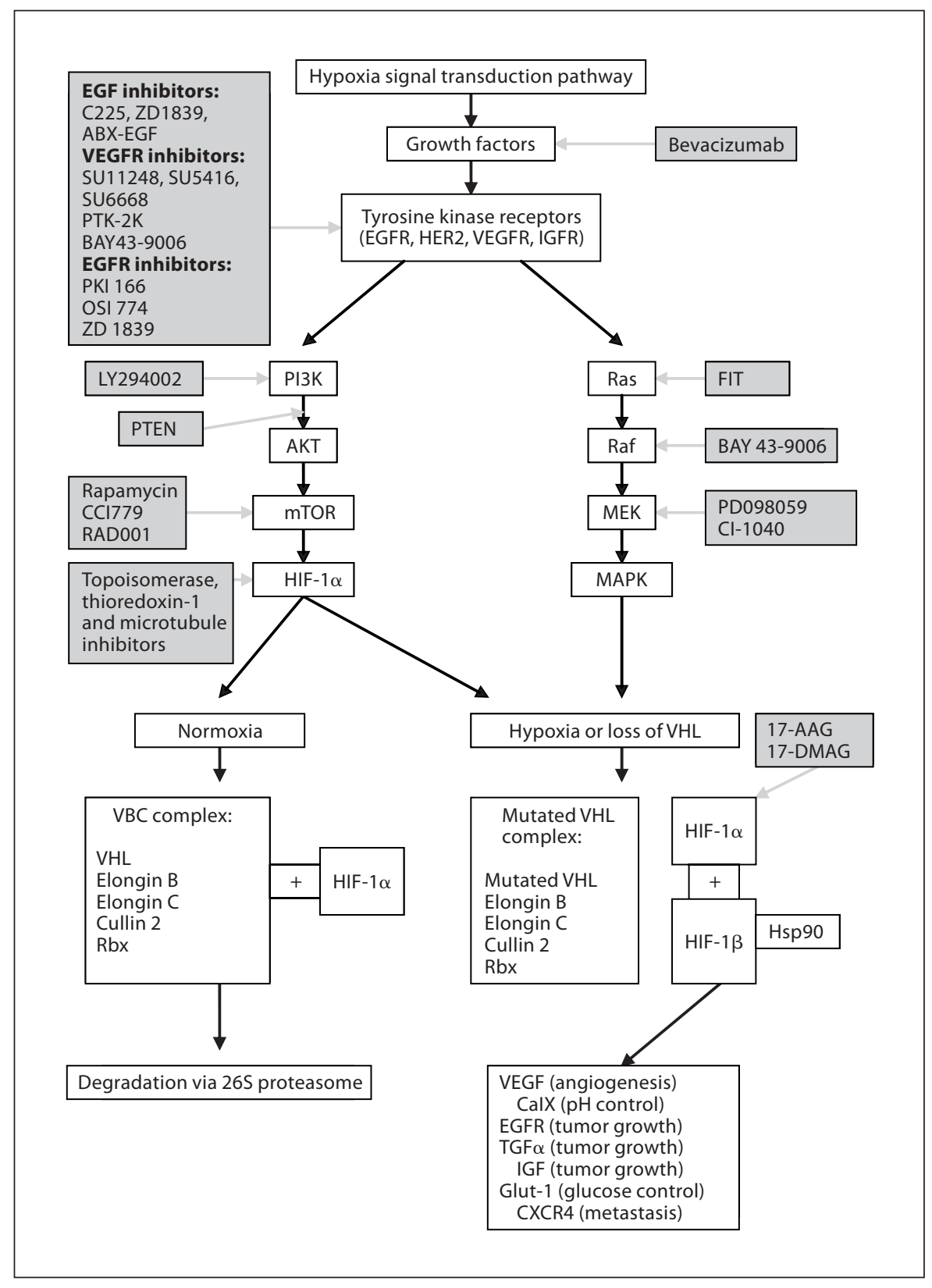

form and is characterized by a predisposition to develop pheochromocytomas in addition to the manifestations of VHL type 1 . The rarest form of VHL is type $2 \mathrm{~B}$, which is characterized by a predisposition to develop pheochromocytomas with little or no tendency to develop RCCs $[75,76]$. The genotype may predict the phenotype that will actually develop, and in some cases this has been demonstrated. Genetic alterations in the VHL gene in type-1 families mostly constitute deletion, nonsense or frame-shift mutations, whereas $90 \%$ of VHL mutations found in type-2 families are mis-sense mutations [25, 76, 77]. A few mis-sense mutations have been described that specifically lead to VHL type 2A [25].

The VHL gene encodes two different protein isoforms. Both isoforms suppress RCC growth in vivo and are referred to as pVHL $[78,79]$. The pVHL functions as a component of an ubiquitin ligase complex (VBC complex), and its best understood function relates to its ability to target and destruct specific proteins [80]. The pVHL forms stable complexes that contain other 
Table 3. Main protein targets of the VHL

\begin{tabular}{ll}
\hline Target protein & Function \\
\hline Hypoxia inducible factors 1 and 2 & Protein transcription \\
Vascular endothelial growth factor & Angiogenesis \\
Glucose transporter protein-1 & Glucose transport \\
Platelet-derived growth factor- $\beta$ & Angiogenesis, mitogenesis \\
Transforming growth factors $\alpha$ and $\beta$ & Epithelial proliferation, mitogenesis \\
Intracellular fibronectin & Epithelial proliferation \\
Erythropoietin & Erythropoiesis \\
Carbonic anhydrases 9 and 12 & Extracellular pH control \\
Chemokine receptor & Metastasis \\
\hline
\end{tabular}

proteins entitled elongin $\mathrm{B}$, elongin $\mathrm{C}, \mathrm{Cul} 2$, and $\mathrm{Rbx} 1$ $[81,82]$. These complexes direct the covalent attachment of polyubiquitin tails to specific proteins, serving as a signal for such proteins to be degraded by the proteasome.

Several pVHL targets have been identified, including the members of the hypoxia-inducible factor- $\alpha$ (HIF- $\alpha$ ) family (HIF- $1 \alpha$, HIF- $2 \alpha$, and HIF- $3 \alpha$ ). The HIF- $1 \alpha$ and HIF- $2 \alpha$, when bound to a HIF- $\beta$ member, form a sequence-specific, DNA-binding transcription factor called HIF. Ordinarily, the HIF- $\alpha$ family members are highly unstable except under low-oxygen conditions. In the presence of oxygen, these proteins become hydroxylated on conserved prolyl residues in a reaction catalyzed by members of the EGLN family [83-86]. pVHL recognizes the hydroxylated HIF- $\alpha$ species and orchestrates their destruction through ubiquitination [87-89].

Since the 1990s, evidence has continued to accumulate demonstrating that hypoxia is a common consequence of the rapid growth of renal cancer (fig. 2) [90, 91]. Molecular studies provide evidence that hypoxia is an important regulator of a network of gene expression with the ability to stimulate and inhibit individual genes and to effect their expression on both posttranscriptional and posttranslational levels [90]. Among these genes are those that control glucose uptake and metabolism (such as the Glut1 glucose transporter and various glycolytic enzymes), extracellular $\mathrm{pH}$ (such as carbonic anhydrase IX), angiogenesis (such as vascular endothelial growth factor, VEGF), erythropoiesis (such as erythropoietin), and mitogenesis (such as TGF- $\alpha$ and PDGF-B). Signaling occurs through various cell surface receptors, including EGFR, HER2, VEGFR and type-I insulin-like growth factor receptor. During normoxia, the VHL complex targets and degrades HIF. In cells that lack pVHL, or when oxygen is limiting, the complex cannot degrade HIF.
HIF- $1 \alpha$ and $2 \alpha$ are upregulated through the phosphatidylinositol 4,5-bisphosphate-AKT-mammalian target of rapamycin pathway (P13K-AKT-mTOR) and Ras/Raf/ $\mathrm{MEK} /$ mitogen-activated protein kinase (MAPK) pathway and they form the transcription factor HIF. HIF is free to accumulate intracellularly and activates the transcription of a cadre of genes that encode proteins essential for cancer cell functions under hypoxic conditions (table 3) $[92,93]$. These considerations explain the frequent overproduction of HIF, as well as its downstream targets, in RCC [80].

The pVHL binds to other cellular proteins, some of which may also be polyubiquitinated or in some other way modulated by pVHL. These proteins include the atypical protein kinase C family members [94], Sp1 [95], heteronuclear ribonucleoprotein hnRNP A2 [96], specific RNA Pol II subunits (Rpbl and hsRBP7) [97, 98], Jade1 [99], Vdu1/2 [100], fibronectin [101], proteins associated with microtubules [102], nuclear factor $\kappa B$ [103, 104], and metalloproteinases [105].

Recently, it has been demonstrated that VHL inactivation in RCC cells disrupts intercellular junctions and cell shape through HIF-independent events, supporting the concept that VHL has additional functions beside its role in the regulation of HIF [106]. Although our knowledge of the functions of pVHL is still incomplete, studies conducted thus far highlight its role as an inhibitor of HIF, and dysregulation of HIF is likely to contribute to the development of RCC [107].

\section{Hereditary PRCC}

Patients with HPRC are at risk for development of bilateral, multi-focal type-1 papillary renal carcinoma [45, 108]. Genetic linkage analysis in HPRC families identi- 
fied the proto-oncogene, c-MET (located at 7q31.1-34) to be responsible for the hereditary form of type-1 papillary renal carcinoma [109]. MET belongs to the family of tyrosine kinases, which transmit signals from the cellular surface to the nucleus [110].

Most HPRC-associated MET mutations are mis-sense mutations located within the tyrosine kinase domain. MET mutations do not require concomitant loss of the remaining MET allele, as is true for the VHL gene. Instead, chromosome 7 duplications leading to trisomy 7 have been found to be associated with gain-of-function MET mutations in a majority of HPRC tumors. Genotyping analyses have demonstrated that chromosome 7 carrying the mutant MET allele is duplicated in these papillary renal tumors $[111,112]$.

MET acts as a transmembrane receptor for the hepatocyte growth factor. Binding of this growth factor induces cellular mitogenesis, morphogenesis and cellular migration, through a growth-stimulating signaling cascade via RAS. It was suggested that mutations in the cytoplasmic kinase domain of the MET gene might lead to constitutive activation without ligand binding and, thus, to continued activation of the signaling cascade leading to out-of-control cellular proliferation. Transfection studies in combination with biological assays showed that carcinogenesis is related to enzymatic activation of MET [113].

\section{Hereditary Leiomyomatosis RCC}

HLRCC is an inherited cancer syndrome in which patients are at risk for the development of cutaneous and uterine leiomyoma and type-2 papillary RCC [114]. Genome linkage analysis linked the syndrome to 1q4244 [115] and identified mutations in the gene for fumarate hydratase $(\mathrm{FH})$ as the causative abnormality [116, 117]. These mutations were found to reduce the activity of FH, an enzyme in the tri-carboxylic acid (Krebs) cycle that is involved in energy production and amino acid metabolism. Reduced enzyme activity and associated $\mathrm{LOH}$ at 1q42-44 in uterine leiomyomas and renal tumors support the function of $\mathrm{FH}$ as a tumor-suppressor gene.

Types of germline FH mutations in HLRCC include protein-truncating mutations, large and in-frame deletions, and mis-sense mutations [115]. Mis-sense FH mutations predisposing to renal cancer have no unusual features, and identical mutations were found in families without renal cancer, suggesting a role for genetic or en- vironmental factors in renal cancer development in hereditary leiomyomatosis [117].

Activation of the hypoxia/angiogenesis pathway may contribute to carcinogenesis in HLRCC. Studies have demonstrated increased expression of transcripts from the hypoxia-responsive genes VEGF and BNIP3. It is possible that failure of the Krebs cycle in HLRCC tumors causes inappropriate signaling of a hypoxic state, leading to angiogenesis and perhaps directly to clonal expansion and tumor growth through a cell-autonomous effect [118]. However, it remains to be elucidated how abnormalities in FH protein expression play a role in HLRCCrelated carcinogenesis.

\section{BHD Syndrome: Chromophobe and Oncocytic Renal Carcinoma and Oncocytoma}

The BHD gene (also known as FLCN) has been mapped at 17p12-q11.2 [66]. Oncocytomas and chromophobe $\mathrm{RCC}$ are the most frequent renal tumors in BHD syndrome, but hybrid-oncocytic renal carcinoma, papillary type 1, and clear-cell RCC have also been reported [119121]. Cytogenetic studies on the clear-cell RCCs have revealed that they are identical to sporadic conventional RCCs, with frequent $3 p$ loss and concomitant VHL inactivation and 5q gain [122]. Studies on hybrid oncocytic tumors have shown few or no consistently found cytogenetic abnormalities [68].

BHD gene alteration is not specific for particular histological types of RCC, unlike abnormalities in VHL (clear-cell) or c-met (papillary) [120]. There is evidence that it acts as a tumor-suppressor gene $[122,123]$. The majority of the mutations detected were predicted to prematurely terminate the BHD protein and to result in loss of its function [120]. Loss of the wild-type BHD allele or somatic frame-shift second-hit mutations were confirmed in renal tumors of relatives with BHD, resulting in bi-allelic inactivation of BHD [120].

Mutation analysis of the $\mathrm{BHD}$ gene has revealed frameshift or termination mutations in the majority of BHD families [66]. There is evidence for possible genotypephenotype associations. A mutational hotspot, a C insertion/deletion in exon 11, is frequently mutated in BHD families. Renal tumors developed with a higher frequency in C-insertion carriers compared with C-deletion carriers, and more frequently in individuals who inherited a putative splice-site mutation in intron 9. The residual mutant protein produced in patients with the $\mathrm{C}$-insertion mutation might have a dominant-negative effect and in- 
terfere with the wild-type BHD protein function, leading to the development of renal tumors. Alternatively, the residual mutant protein encoded by the C-insertion mutation might predispose kidney cells to form a renal tumor [120].

The BHD gene product, folliculin, is highly conserved, and reduced BHD expression was demonstrated in renal tumors from patients with BHD, regardless of the histological type [125]. Nevertheless, the protein does not belong to any known protein family, and its exact function remains to be elucidated [68].

\section{Other Hereditary Renal Cancers}

\section{Germline Constitutional Chromosome 3}

\section{Translocations}

Clear-cell RCC segregation was found in families that show constitutional balanced translocations involving chromosome 3 [126]. The abnormalities found included: $\mathrm{t}(3 ; 8)(\mathrm{p} 14 ; \mathrm{q} 24)$ [127], $\mathrm{t}(3 ; 6)(\mathrm{p} 13 ; \mathrm{q} 25.1)$ [128], t(2;3)(q35; q21) [129], t(3;4)(p13;p16) [130], t(2;3)(q33;q21) [131], $\mathrm{t}(3 ; 6)(\mathrm{q} 12 ; \mathrm{q} 15)$ [132] and $\mathrm{t}(1 ; 3)(\mathrm{q} 32 ; \mathrm{q} 13.3)$ [133].

Molecular studies in these families revealed that some of them carried different VHL mutations in the allele derived from the remaining 'normal' chromosome 3. The concurrent observations of loss of $3 p$ derivative chromosomes and somatic VHL mutations led to the proposition of a three-step model for carcinogenesis [4, 25, 134, 135]. The first hit would be the occurrence of a germline chromosome 3 translocation, while non-disjunctional loss of the derivative chromosome that carries the $3 \mathrm{p}$ segment would represent the second step. Finally, the third step would involve a somatic mutation in the remaining $3 p$ allele of an RCC-related tumor-suppressor gene such as VHL. However, since some of the analyzed familial tumors did not carry VHL mutations, it seems likely that other tumor-suppressor genes located in the $3 \mathrm{p}$ arm could also be involved in the development of conventional RCC.

\section{Familial Clear-Cell RCC with No Known Genetic Abnormality}

Several families have been reported with a cluster of clear-cell RCCs in which the renal tumors were unrelated to germline VHL mutations, chromosome 3 translocations or MET mutations [10,11]. These tumors may represent an increased predisposition to develop a first hit in unknown genes within renal epithelial cells that leads to carcinogenesis.
Renal Medullary Cancers in Sickle Cell Trait/Disease

Around 90 cases of advanced renal medullary cancer have been reported, mostly in young, male Africans with sickle cell trait, some with sickle cell disease or other hemoglobinopathies [136].

\section{Novel Molecular Therapeutics}

Molecular targeting against RCC has already been studied in several clinical trials (table 4). The VHL pathway can be targeted by blocking the transcription of HIF through inhibition of the mTOR pathway with rapamycin and analogues $[93,137]$, inhibition of the ubiquitin/ proteasome system with bortezomib [138] and inhibition of heat shock protein 90 with geldenamycin and 17-(allylamino)-17-demethoxygeldanamycin [139]. A number of other agents downregulate HIF, including HDAC inhibitors [140], topoisomerase I inhibitors [141], thioredoxin-1 inhibitors [142], and microtubule disrupters [143].

The downstream targets of HIF, such as VEGFR, EGFR and PDGFR, can also be manipulated in several ways. BAY 43-9006 is a potent inhibitor of the cellular serine/threonine kinase receptor pathway, and is active against VEGFR and PDGFR, leading to anti-angiogenesis, the inhibition of tumor cell proliferation [144]. Bevacizumab, a neutralizing antibody against VEGF, has been shown to delay progression of metastatic RCC [145].

Cetuximab and gefitinib, which target EGFR have showed no activity against RCC [146, 147]. Combination agents such as ZD6474 that can inhibit at least two arms of the downstream HIF pathway (i.e. VEGFR and EGFR) are currently under clinical evaluation [148]. SU-011248, an orally bioavailable indolinone acting as a signal transduction inhibitor of VEGFR, PDGFR and the c-kit tyrosine kinase, showed encouraging results and is under evaluation in a phase-III trial [149]. Thalidomide is also a potent in vivo angiogenesis inhibitor [150]. Due to its critical role in RCC pathobiology, carbonic anhydrase IX has been exploited as a potential target for immunotherapy $[151,152]$.

Studies upon the activating point mutations in c-MET found in type-1 papillary RCC suggest at least three strategies for therapeutic development: (a) block kinase activation with small molecule inhibitors of ATP binding; (b) block HGF-MET interaction, and (c) block interactions between activated c-MET and downstream intracellular signaling molecules [153]. 
Table 4. Novel molecular therapeutics for RCC

\begin{tabular}{|c|c|}
\hline Category & Mode of action \\
\hline \multicolumn{2}{|l|}{ Inhibition of the hypoxia-inducible pathway } \\
\hline Rapamycin & Inhibits PI3K-AKT-mTOR signal transduction pathway \\
\hline Rapamycin analogues CCI-779 RAD001 & Inhibits PI3K-AKT-mTOR signal transduction pathway \\
\hline Raf kinase inhibitors (BAY 43-9006) & Targets Raf kinase + VEGFR-2 \\
\hline Proteasome inhibitors (bortezomib, PS-341) & Inhibits $26 \mathrm{~S}$ proteasome catalytic activity, thus, preventing proteolysis \\
\hline \multicolumn{2}{|c|}{ Epidermal growth factor receptor (EGFR) inhibitors } \\
\hline Gefitinib, ZD1839 & Inhibits EGFR tyrosine kinase \\
\hline Erlotinib, OSI 774 & Inhibits EGFR tyrosine kinase \\
\hline \multicolumn{2}{|l|}{ Monoclonal antibody therapy } \\
\hline WX-250 & Antibody that targets VEGF \\
\hline Bevacizumab & Neutralizing antibody that targets VEGF \\
\hline Panitumumab, ABX-EGF & Antibody that targets EGF receptor (EGFR) \\
\hline MDX-010 & Antibody that targets CTLA- 4 to block lymphocyte activity \\
\hline Cetuximab (C225), IMC-C225 & Antibody that targets EGFR \\
\hline \multicolumn{2}{|l|}{ Anti-angiogenesis agents } \\
\hline Thalidomide & $\begin{array}{l}\text { Immunomodulatory agent with multiple actions, including VEGF + basic fibroblast } \\
\text { growth factor inhibition }\end{array}$ \\
\hline Thalidomide analogues (CC5013) & $\begin{array}{l}\text { Immunomodulatory agent with multiple actions, including VEGF + basic fibroblast } \\
\text { growth factor inhibition }\end{array}$ \\
\hline $\begin{array}{l}\text { Endothelin-1 receptor antagonists } \\
\text { (atrasentan, ABT-627) }\end{array}$ & Selective endothelin-1 receptor antagonist \\
\hline Indolinone (SU-011248) & Inhibits VEGFR, PDGFR + FLT3 signal transduction, + c-kit tyrosine kinase \\
\hline VEGFR + EGFR inhibitors (ZD 6474) & Targets VEGFR 1,V EGFR \\
\hline VEGFR inhibitors (PTK 787) & Selectively targets VEGFR 1, VEGFR-2 + VEGFR-3 tyrosine kinases \\
\hline
\end{tabular}

\section{Epilogue}

Numerous molecular studies upon RCCs have been performed, making RCC one of the best genetically understood cancers. With the availability of advanced molecular tools such as genomics, transcriptomics and proteomics the molecular pathogenesis of RCC has been elu- cidated. The understanding of RCC carcinogenesis might lead to a novel tumor classification and to better treatment outcomes with the aid of novel anticancer agents. The role of surgery before or after administration of novel molecular agents in metastatic disease, and the role of these agents in the neo-adjuvant or adjuvant setting in localized disease will need further evaluation.

\section{References}

1 Linehan WM, Grubb RL, Coleman JA, et al: The genetic basis of cancer of kidney cancer: implications for gene-specific clinical management BJU Int 2005;95(suppl 2):2-7.

2 Pavlovich CP, Schmidt LS: Searching for the hereditary causes of renal-cell carcinoma. Nat Rev Cancer 2004;4:381-393.

-3 Hansel DE: Genetic alterations and histopathologic findings in familial renal cell carcinoma. Histol Histopathol 2006;21:437444
Kovacs G, Kung HF: Nonhomologous chromatid exchange in hereditary and sporadic renal cell carcinomas. Proc Natl Acad Sci USA 1991;88:194-198.

5 Van den Berg A, Buys CHCM: Involvement of multiple loci on chromosome 3 in renal cell cancer development. Genes Chromosomes Cancer 1997;19:59-76.

6 Alimov A, Kost-Alimova M, Liu J, et al: Combined $\mathrm{LOH} / \mathrm{CGH}$ analysis proves the existence of interstitial $3 p$ deletions in renal cell carcinoma. Oncogene 2000;19:1392-1399.
7 Knudson AG: Mutation and cancer: statistical study of retinoblastoma. Proc Natl Acad Sci USA 1971;68:820-823.

-8 Kovacs G, Emanuel A, Neumann HP, et al: Cytogenetics of renal cell carcinomas associated with von Hippel-Lindau disease. Genes Chromosomes Cancer 1991;3:256-262.

-9 Gnarra JR, Tory K, Weng Y, et al: Mutations of the VHL tumour suppressor gene in renal carcinoma. Nat Genet 1994;7:85-90. 
10 Teh BT, Giraud S, Sari NF, et al: Familial non-VHL non-papillary clear-cell renal cancer. Lancet 1997;349:848-849.

-11 Woodward ER, Clifford SC, Astuti D, et al: Familial clear cell renal cell carcinoma (FCRC): clinical features and mutation analysis of the VHL, MET, and CUL2 candidate genes. J Med Genet 2000;37:348-353.

-12 Martinez A, Fullwood P, Kishida T, et al: Role of chromosome 3p12-p21 tumour suppressor genes in clear cell renal cell carcinoma: analysis of VHL dependent and VHL independent pathways of tumorigenesis. Mol Pathol 2000;53:137-144.

13 Lott ST, Lovell M, Naylor SL, et al: Physical and functional mapping of a tumor suppressor locus for renal cell carcinoma within chromosome 3q12. Cancer Res 1998;58: 3533-3537.

- 14 Jülicher K, Marquitan G, Werner N, et al: Novel tumor suppressor locus in human chromosome region 3p14.2. J Natl Cancer Inst 1999;91:1563-1568.

15 Lovell M, Lott ST, Wong P, et al: The genetic locus NRC-1 within chromosome 3p12 mediates tumor suppression in renal cell carcinoma independently of histological type, tumor microenvironment, and VHL mutation. Cancer Res 1999;59:2182-2189.

16 Wang L, Darling J, Zhang JS, et al: Loss of expression of the DDR1 gene at chromosome segment 3p21.1 in renal cell carcinoma. Genes Chromosomes Cancer 2000;27:1-10.

17 Dreijerink K, Braga E, Kuzmin I, et al: Candidate TSG, RASSF1A, from human chromosome 3p21.3 is involved in kidney tumorigenesis. Proc Natl Acad Sci USA 2001;98: 7504-7509.

18 Burbee DG, Forgacs E, Zöchbauer-Müller S, et al: Epigenetic inactivation of RASSF1A in lung and breast cancers and malignant phenotype suppression. J Natl Cancer Inst 2001; 93:691-699.

19 Engel JD, Kundu SD, Yang T, et al: Transforming growth factor-beta type II receptor confers tumor suppressor activity in murine renal carcinoma (renca) cells. Urology 1999; 54:164-170.

20 Ramp U, Jaquet K, Reinecke P, et al: Acquisition of TGF-beta 1 resistance: an important progression factor in human renal cell carcinoma. Lab Invest 1997;76:739-739.

-21 Kundu SD, Kim IY, Zelner D, et al: Absence of expression of transforming growth factorbeta type II receptor is associated with an aggressive growth pattern in a murine renal carcinoma cell line, Renca. J Urol 1998;160: 1883-1888.

$\checkmark 22$ Cardillo MR, Lazzereschi D, Gandini O, et al: Transforming growth factor-beta pathway in human renal cell carcinoma and surrounding normal-appearing renal parenchyma. Anal Quant Cytol Histol 2001;23: 109-117.
23 Junker U, Haufe CC, Nuske K, et al: Elevated plasma TGF-betal in renal disease: cause or consequence? Cytokine 2000;12:1084-1091.

24 Audebert M, Chevillard S, Levalois C, et al: Alterations of the DNA repair gene OGG1 in human clear cell carcinomas of the kidney. Cancer Res 2000;60:4740-4744.

25 Bodmer D, van den Hurk W, van Groningen JJM, et al: Understanding familial and nonfamilial renal cell cancer. Hum Mol Genet 2002;11:2489-2498.

26 Bugert P, Pesti T, Kovacs G: The tcf17 gene at chromosome $5 \mathrm{q}$ is not involved in the development of conventional renal cell carcinoma. Int J Cancer 2000;86:806-810.

27 Yang ZQ, Yoshida MA, Fukuda Y, et al: Molecular cytogenetic analysis of 17 renal cancer cell lines: increased copy number at 5q31-33 in cell lines from nonpapillary carcinomas. Jpn J Cancer Res 2000;91:156-163.

28 Gurova KV, Hill JE, Razorenova OV, et al: p53 Pathway in renal cell carcinoma is repressed by a dominant mechanism. Cancer Res 2004;64:1951-1958.

29 Walther MM, Enquist EG, Jennings SB, et al: Molecular genetics of renal cell carcinoma; in Vogelzang NJ, Scardino PT, Shipley WU, Coffey DS (eds): Comprehensive Textbook of Genitourinary Oncology, ed 2. Philadelphia, Lippincott, Williams \& Wilkins, 2000, pp 116-128.

30 Rochlitz CF, Peter S, Wiliroth G, et al: Mutations in the ras protooncogenes are rare events in renal cell cancer. Eur J Cancer 1992; 28:333-336.

31 Latif Z, Waters AD, Bartlett JMS, et al: Gene amplification and over expression of HER2 in renal cell carcinoma. BJU Int 2002;89:59.

32 Kinouchi T, Saiki S, Naoe T, et al: Correlation of c-myc expression with nuclear pleomorphism in human renal cell carcinoma. Cancer Res 1989;49:3627-3630.

-33 Slamon DJ, deKernion JB, Verma IM, et al: Expression of cellular oncogenes in human malignancies. Science 1984;224:256-262.

34 Argiles A, Kraft N, Ootaka T, et al: Epidermal growth factor and transforming growth factor alpha stimulate or inhibit proliferation of a human renal adenocarcinoma cell line depending on cell status: differentiation of the two pathways by $\mathrm{G}$ protein involvement. Cancer Res 1992;52:4356-4560.

35 Petrides PE, Bock S, Bovens J, Hofmann R, Jakse G: Modulation of pro-epidermal growth factor, pro-transforming growth factor alpha and epidermal growth factor receptor gene expression in human renal carcinomas. Cancer Res 1990;50:3934-3939.

36 Atlas I, Mendelsohn J, Baselga J, et al: Growth regulation of human renal carcinoma cells: role of transforming growth factor alpha. Cancer Res 1992;52:3335-3339.

\37 Gomella LG, Anglard P, Sargent ER, et al: Epidermal growth factor receptor gene analysis in renal cell carcinoma. J Urol 1990;143: 191-193.
38 De Paulsen N, Brychzy A, Fournier MC, et al: Role of transforming growth factor- $\alpha$ in von Hippel-Lindau (VHL) (-/-) clear cell renal carcinoma cell proliferation: a possible mechanism coupling VHL tumor suppressor inactivation and tumorigenesis. Proc Natl Acad Sci USA 2001;98:1387-1392.

39 Kochevar GJ, Stanek JA, Rucker EB: Truncated fibronectin. An autologous growthpromoting substance secreted by renal carcinoma cells. Cancer 1992;69:2311-2315.

40 Kobayashi T, Honke K, Gasa S, et al: Hepatocyte growth factor elevates the activity levels of glycolipid sulfotransferases in renal cell carcinoma cells. Eur J Biochem 1994;219: 407-413.

41 Nishimura N, Kanda S, Yogi Y, et al: Secretion of autocrine growth-promoting activity by renal-carcinoma cells treated with 5 -fluorouracil. Int J Cancer 1992;52:105-109.

42 Klotz LH, Kulkarni C, Mills G: End stage renal disease serum contains a specific renal cell growth factor. J Urol 1991;145:156-160.

43 Pavlovich CP, Schmidt LS, Phillips JL: The genetic basis of renal cell carcinoma. Urol Clin North Am 2003;30:437-454.

44 Delahunt B, Eble JN, McCredie MR, et al: Morphologic typing of papillary renal cell carcinoma: comparison of growth kinetics and patient survival in 66 cases. Hum Pathol 2001;32:590-595.

45 Lubensky IA, Schmidt L, Zhuang Z, et al: Hereditary and sporadic papillary renal carcinomas with c-met mutations share a distinct morphological phenotype. Am J Pathol 1999; 155:517-526.

46 Jiang F, Richter J, Schraml P, et al: Chromosomal imbalances in papillary renal cell carcinoma: genetic differences between histological subtypes. Am J Pathol 1998;153: 1467-1473.

47 Kovacs G, Fuzesi L, Emanual A, et al: Cytogenetics of papillary renal cell tumors. Genes Chromosomes Cancer 1991;3:249-255.

48 Reutzel D, Mende M, Naumann S, et al: Genomic imbalances in 61 renal cancers from the proximal tubulus detected by comparative genomic hybridization. Cytogenet Cell Genet 2001;93:221-227.

49 Heimann P, El Housni H, Ogur G, et al: Fusion of a novel gene, RCC17, to the TFE3 gene in $\mathrm{t}(\mathrm{X} ; 17)$ (p11.2;q25.3)-bearing papillary renal cell carcinomas. Cancer Res 2001;61: 4130-4135.

50 Weterman MAJ, Wilbrink M, Geurts van Kessel A: Fusion of the transcription factor TFE3 gene to a novel gene, PRCC, in $\mathrm{t}(\mathrm{X} ; 1)(\mathrm{p} 11 ; \mathrm{q} 21)$-positive papillary renal cell carcinomas. Proc Natl Acad Sci USA 1996; 93:15294-15298.

51 Beckmann H, Su LK, Kadesh T: TFE3: a helix-loop-helix protein that activates transcription through the immunoglobulin enhancer $\mu E 3$ motif. Genes Dev 1990;4: 167-179. 
-52 Weterman MAJ, van Groningen JM, Jansen A, et al: Nuclear localization and transactivating capacities of the papillary renal cell carcinoma-associated TFE3 and PRCC (fusion) proteins. Oncogene 2000;19:69-74.

- 53 Weterman MAJ, van Groningen JM, den Hartog A, et al: Transformation capacities of the papillary renal cell carcinoma-associated PRCCTFE3 and TFE3PRCC fusion genes. Oncogene 2001;20:1414-1424.

54 Wassmann K, Benezra R: Mitotic checkpoints: from yeast to cancer. Curr Opin Genet Dev 2001;11:83-90.

55 Chen J, Fang G: MAD2B is an inhibitor of the anaphase-promoting complex. Genes Dev 2001;15:1765-1770.

56 Peters JM: The anaphase-promoting complex: proteolysis in mitosis and beyond. Mol Cell 2002;9:931-943.

- 57 Pfleger CM, Salic A, Lee E, et al: Inhibition of Cdh1-APC by MAD2L2: a novel mechanism of regulating Cdh1. Genes Dev 2001; 15:1759-1764.

-58 Clark J, Lu YJ, Sidhar S, Parker C, et al: Fusion of the splicing factor genes PSF and NonO ( $\mathrm{p} 54 \mathrm{nrb}$ ) to the TFE3 gene in papillary renal cell carcinoma. Oncogene 1997; 15: 2233-2239.

-59 Skalsky YM, Ajuh PM, Parker C, et al: PRCC, the commonest TFE3 fusion partner in papillary renal carcinoma is associated with premRNA splicing factors. Oncogene 2001;20: 178-187.

60 Schmidt L, Junker K, Nakaigawa N, et al: Novel mutations of the MET proto-oncogene in papillary renal carcinomas. Oncogene 1999; 18:2343-2350.

61 Glukhova L, Lavialle C, Fauvet D, et al: Mapping of the $7 \mathrm{q} 31$ subregion common to the small chromosome 7 derivatives from two sporadic papillary renal cell carcinomas: increased copy number and overexpression of the MET proto-oncogene. Oncogene 2000; 19:754-761.

62 Nagashima Y, Inayama Y, Kato Y, et al: Pathological and molecular biological aspects of the renal epithelial neoplasms, up-to-date. Pathol Int 2004;54:377-386.

-63 Schwerdtle RF, Storkel S, Neuhaus C, et al: Allelic losses at chromosomes 1p, 2p, 6p, 10p, $13 q, 17 p$, and 21q significantly correlate with the chromophobe subtype of renal cell carcinoma. Cancer Res 1996, 56:2927-2930.

64 Velickovic M, Delahunt B, Storkel S, et al: VHL and FHIT locus loss of heterozygosity is common in all renal cancer morphotypes but differs in pattern and prognostic significance. Cancer Res 2001;61:4815-4819.

65 Contractor H, Zariwala M, Bugert P, et al: Mutation of the $\mathrm{p} 53$ tumour suppressor gene occurs preferentially in the chromophobe type of renal cell tumour. J Pathol 1997;181: 136-139.
66 Nickerson M, Warren M, Toro J, et al: Mutations in a novel gene lead to kidney tumors, lung wall defects, and benign tumors of the hair follicle in patients with the Birt-HoggDubé syndrome. Cancer Cell 2002;2:157164.

67 Fuzesi L, Cober M, Mittermayer C: Collecting duct carcinoma: cytogenetic characterization. Histopathology 1992;21:155-160.

68 Verdorfer I, Culig Z, Hobisch A, et al: Characterisation of a collecting duct carcinoma by cytogenetic analysis and comparative genomic hybridisation. Int J Oncol 1998; 13: 461-464.

69 Uzzo RG, Cairns P, Al-Saleem T, Hudes G, Haas N, Greenberg RE, Kolenko V: The basic biology and immunobiology of renal cell carcinoma: considerations for the clinician. Urol Clin North Am 2003;30:423-426.

70 Latif F, Tory K, Gnarra JR, et al: Identification of the von Hippel-Lindau disease tumor suppressor gene. Science 1993;260:1317-1320.

71 Knudson AG Jr: Genetics of human cancer. Annu Rev Genet 1986;20:231-251.

72 Stolle C, Glenn G, Zbar B, et al: Improved detection of germline mutations in the von Hippel-Lindau disease tumor suppressor gene. Hum Mutat 1998;12:417-423.

73 Prowse AH, Webster AR, Richards FM, et al: Somatic inactivation of the VHL gene in von Hippel-Lindau disease tumors. Am J Hum Genet 1997;60:765-771.

74 Uzzo RG, Novick AC: von Hippel-Lindau syndrome: clinical and molecular considerations for the urologist. AUA Update Ser 1999;18:137-144.

75 Choyke PL, Glenn GM, Walther MM, et al: von Hippel-Lindau disease: genetic, clinical, and imaging features. Radiology 1995;194: 629-642.

76 Chen F, Kishida T, Yao M, et al: Germline mutations in the von Hippel-Lindau disease tumor suppressor gene: correlations with phenotype. Hum Mutat 1995;5:66-75.

77 Crossey PA, Richards FM, Foster K, et al: Identification of intragenic mutations in the von Hippel-Lindau disease tumour suppressor gene and correlation with disease phenotype. Hum Mol Genet 1994;3:1303-1308.

78 Schoenfeld A, Davidowitz E, Burk R: A second major native von Hippel-Lindau gene product, initiated from an internal translation start site, functions as a tumor suppressor. Proc Natl Acad Sci USA 1 1998;95:88178822.

79 Blankenship C, Naglich J, Whaley J, et al: Alternate choice of initiation codon produces a biologically active product of the von Hippel Lindau gene with tumor suppressor activity. Oncogene 1999;18:1529-1535.

80 Kaelin WG Jr: The von Hippel-Lindau tumor suppressor gene and kidney cancer. Clin Cancer Res 2004;10(suppl):6290-6295.

-81 Kim W, Kaelin WG Jr: The von Hippel-Lindau tumor suppressor protein: new insights into oxygen sensing and cancer. Curr Opin Genet Dev 2003;13:55-60.
82 George DJ, Kaelin WG Jr: The von HippelLindau protein, vascular endothelial growth factor, and kidney cancer. N Engl J Med 2003:349:419-421.

83 Epstein A, Gleadle J, McNeill L, et al: Elegans EGL-9 and mammalian homologs define a family of dioxygenases that regulate HIF by prolyl hydroxylation. Cell 2001;107:43-54.

84 Berra E, Benizri E, Ginouves A, et al: HIF prolyl-hydroxylase 2 is the key oxygen sensor setting low steady-state levels of HIF-1alpha in normoxia. EMBO J 2003;22:4082-4090.

$>85$ Ivan M, Haberberger T, Gervasi DC, et al: Biochemical purification and pharmacological inhibition of a mammalian prolyl hydroxylase acting on hypoxia-inducible factor. Proc Natl Acad Sci USA 2002;99: 13459-13464.

86 Bruick R, McKnight S: A conserved family of prolyl-4-hydroxylases that modify HIF. Science 2001;294:1337-1340.

87 Ivan M, Kondo K, Yang H, et al: HIFalpha targeted for VHL-mediated destruction by proline hydroxylation: implications for $\mathrm{O}_{2}$ sensing. Science 2001;292:464-468.

$\checkmark 88$ Yu F, White S, Zhao Q, et al: HIF-1alpha binding to VHL is regulated by stimulussensitive proline hydroxylation. Proc Natl Acad Sci USA 2001;98:9630-9635.

89 Jaakkola P, Mole D, Tian Y, et al: Targeting of HIF-alpha to the von Hippel-Lindau ubiquitylation complex by $\mathrm{O} 2$-regulated prolyl hydroxylation. Science 2001;292:468-472.

90 Hockel M, Vaupel P: Tumor hypoxia: definitions and current clinical, biologic, and molecular aspects. J Natl Cancer Inst 2001;93: 266-276.

91 Lidgren A, Hedberg Y, Grankvist K, et al: The expression of hypoxia-inducible factor lalpha is a favorable independent prognostic factor in renal cell carcinoma. Clin Cancer Res 2005;1:1129-1135.

92 Ohh M, Park CW, Ivan M, et al: Ubiquitination of hypoxia-inducible factor requires direct binding to the beta-domain of the von Hippel-Lindau protein. Nat Cell Biol 2000;2: 423-427.

93 Pantuck AJ, Zeng G, Belldegrum AS, et al: Pathobiology, prognosis, and targeted therapy for renal cell carcinoma. Exploiting the hypoxia-induced pathway. Clin Cancer Res 2003:9:4641-4652.

94 Okuda H, Saitoh K, Hirai S, et al: The von Hippel-Lindau tumor suppressor protein mediates ubiquitination of activated atypical protein kinase C J Biol Chem 2001;276: 43611-43617.

95 Cohen H, Zhou M, Welsh A, et al: An important von Hippel-Lindau tumor suppressor domain mediates Sp1-binding and self-association. Biochem Biophys Res Commun 1999;266:43-50.

-96 Pioli PA, Rigby WF: The von Hippel-Lindau protein interacts with heteronuclear ribonucleoprotein a2 and regulates its expression. J Biol Chem 2001;276:40346-40352. 
$\$ 97$ Kuznetsova AV, Meller J, Schnell PO, et al: von Hippel-Lindau protein binds hyperphosphorylated large subunit of RNA polymerase II through a proline hydroxylation motif and targets it for ubiquitination. Proc Natl Acad Sci USA 2003;100:2706-2711.

$\$ 98$ Na X, Duan HO, Messing EM, et al: Identification of the RNA polymerase II subunit hsRPB7 as a novel target of the von HippelLindau protein. EMBO J 2003;22:42494259.

-99 Zhou MI, Wang H, Ross JJ, et al: The von Hippel-Lindau (VHL) tumor suppressor stabilizes novel PHD protein Jade-1. J Biol Chem 2002;277:39887-39898.

100 Li Z, Na X, Wang D, et al: Ubiquitination of a novel deubiquitinating enzyme requires direct binding to von Hippel-Lindau tumor suppressor protein. J Biol Chem 2002;277: 4656-4662.

101 Ohh M, Yauch RL, Lonergan KM, et al: The von Hippel-Lindau tumor suppressor protein is required for proper assembly of an extracellular fibronectin matrix. Mol Cell 1998;1:959-968.

- 102 Hergovich A, Lisztwan J, Barry R, et al: Regulation of microtubule stability by the von Hippel-Lindau tumour suppressor protein pVHL. Nat Cell Biol 2003;5:64-70.

- 103 An J, Rettig MB: Mechanism of von HippelLindau protein-mediated suppression of nuclear factor kappa B activity. Mol Cell Biol 2005;25:7546-7556.

104 Atkins DJ, Gingert C, Justnhoven C, et al: Concomitant deregulation of HIFlalpha and cell cycle proteins in VHL-mutated renal cell carcinomas. Virchows Arch 2005; 447:634-642.

105 Petrella BL, Lohi J, Brinckerhoff CE: Identification of membrane type-1 matrix metalloproteinase as a target of hypoxia-inducible factor-2 alpha in von Hippel-Lindau renal cell carcinoma. Oncogene 2005;3: 1043-1052.

106 Calzada MJ, Esteban MA, Feijoo-Cuaresma M, et al: von Hippel-Lindau tumor suppressor protein regulates the assembly of intercellular junctions in renal cancer cells through hypoxia-inducible factor-independent mechanisms. Cancer Res 2006;66: 1553-1560.

107 Maina EN, Morris MR, Zatyka M, et al: Identification of novel VHL target genes and relationship to hypoxic response pathways. Oncogene 2005;30:4549-4558.

-108 Ornstein DK, Lubensky IA, Venzon D, et al: Prevalence of microscopic tumors in normal appearing renal parenchyma from patients with hereditary papillary renal cancer. J Urol 2000;163:431-433.

-109 Schmidt L, Duh F-M, Chen F, et al: Germline and somatic mutations in the tyrosine kinase domain of the MET proto-oncogene in papillary renal carcinomas. Nat Genet 1997;16:68-73.
110 Dean M, Park M, Le Beau MM, et al: The human met oncogene is related to the tyrosine kinase oncogenes. Nature 1985;318: 385-388.

111 Fischer J, Palmedo G, von Knobloch R, et al: Duplication and overexpression of the mutant allele of the MET proto-oncogene in multiple hereditary papillary renal cell tumours. Oncogene 1998;17:733-739.

112 Zhuang Z, Park WS, Pack S, et al: Trisomy 7-harbouring non-random duplication of the mutant MET allele in hereditary papillary renal carcinomas. Nat Genet 1998;20: 66-69.

113 Jeffers M, Fiscella M, Webb CP, et al: The mutationally activated Met receptor mediates motility and metastasis. Proc Natl Acad Sci USA 1998;95:14417-14422.

114 Zbar B, Glenn G, Lubensky I, et al: Hereditary papillary renal cell carcinoma: clinical studies in 10 families. J Urol 1995;153:907912.

115 Tomlinson IP, Alam NA, Rowan AJ, et al: Germline mutations in $\mathrm{FH}$ predispose to dominantly inherited uterine fibroids, skin leiomyomata and papillary renal cell cancer. Nat Genet 2002;30:406-410.

116 Toro JR, Nickerson ML, Wei MH, et al: Mutations in the fumarate hydratase gene cause hereditary leiomyomatosis and renal cell cancer in families in North America. Am J Hum Genet 2003;73:95-106.

117 Alam NA, Olpin S, Rowan A, et al: Missense mutations in fumarate hydratase in multiple cutaneous and uterine leiomyomatosis and renal cell cancer. J Mol Diagn 2005;7:437-443.

118 Pollard P, Wortham N, Barclay E, et al: Evidence of increased microvessel density and activation of the hypoxia pathway in tumours from the hereditary leiomyomatosis and renal cell cancer syndrome. J Pathol 2005;205:41-49.

119 Pavlovich CP, Grubb RL 3rd, Hurley K, et al: Evaluation and management of renal tumors in the Birt-Hogg-Dubé syndrome. J Urol 2005 173:1482-1486.

120 Schmidt LS, Nickerson ML, Warren MB, et al: Germline BHD-mutation spectrum and phenotype analysis of a large cohort of families with Birt-Hogg-Dubé syndrome. Am J Hum Genet 2005;76:1023-1033.

121 Khoo SK, Kahnoski K, Sugimura J et al: Inactivation of BHD in sporadic renal tumors. Cancer Res 2003;63:4583-4587.

122 Okimoto K, Sakurai J, Kobayashi T, et al: A germ-line insertion in the Birt-Hogg-Dubé $(B H D)$ gene gives rise to the Nihon rat model of inherited renal cancer. Proc Natl Acad Sci USA 2004 101:2023-2027.

123 Lingaas F, Comstock KE, Kirkness EF, et al: A mutation in the canine $B H D$ gene is associated with hereditary multifocal renal cystadenocarcinoma and nodular dermatofibrosis in the German shepherd dog. Hum Mol Genet 2003;12:3043-3053.
124 Pavlovich CP, Walther MM, Eyler RA, et al: Renal tumors in the Birt-Hogg-Dubé syndrome. Am J Surg Pathol 2002;26:15421552.

125 Warren MB, Torres-Cabala CA, Turner ML, et al: Expression of Birt-Hogg-Dubé mRNA in normal and neoplastic human tissues. Mod Pathol 2004;17:998-1011.

-126 Rodrí́guez-Perales S, Meléndez B, Gribble $\mathrm{SM}$, et al: Cloning of a new familial $\mathrm{t}(3 ; 8)$ translocation associated with conventional renal cell carcinoma reveals a $5 \mathrm{~kb}$ microdeletion and no gene involved in the rearrangement. Hum Mol Genet 2004;13:983990.

127 Cohen, AJ, Li FP, Berg S, et al: Hereditary renal-cell carcinoma associated with a chromosomal translocation. N Engl J Med 1979;301:592-595.

128 Kovacs G, Brusa P, De Riese W: Tissue-specific expression of a constitutional $3 ; 6$ translocation: development of multiple bilateral renal-cell carcinomas. Int J Cancer 1989;43:422-427.

129 Koolen MI, van der Meyden AP, Bodmer D: A familial case of renal cell carcinoma and a t $(2 ; 3)$ chromosome translocation. Kidney Int 1998;53:273-275.

130 van Kessel A, Wijnhoven H, Bodmer D, et al: Renal cell cancer: chromosome 3 translocat ${ }^{\mathrm{i}}$ ons as risk factors. J Natl Cancer Inst 1999;91:1159-1160.

131 Podolski J, Byrski T, Zajaczek S, et al: Characterization of a familial RCC-associated $\mathrm{t}(2 ; 3)(\mathrm{q} 33 ; \mathrm{q} 21)$ chromosome translocation. J Hum Genet 2001;46:685-693.

132 Eleveld MJ, Bodmer D, Merkx G, et al: Molecular analysis of a familial case of renal cell cancer and a t(3;6)(q12;q15). Genes Chromosomes Cancer 2001;31:23-32.

133 Kanayama H, Lui WO, Takahashi M, et al: Association of a novel constitutional translocation $\mathrm{t}(1 \mathrm{q} ; 3 \mathrm{q})$ with familial renal cell carcinoma. J Med Genet 2001;38:165-170.

134 Schmidt L, Li F, Brown RS, et al: Mechanism of tumorigenesis of renal carcinomas associated with the constitutional chromosome 3;8 translocation. Cancer J Sci Am 1995;1:191.

-135 Bodmer D, Eleveld MJ, Ligtenberg MJ, et al: An alternative route for multistep tumorigenesis in a novel case of hereditary renal cell cancer and a $\mathrm{t}(2 ; 3)(\mathrm{q} 35 ; \mathrm{q} 21)$ chromosome translocation. Am J Hum Genet 1998; 62:1475-1483.

136 Simpson L, He X, Pins M, et al: Renal medullary carcinoma and ABL gene amplification. J Urol 2005 173:1883-1888.

137 Atkins MB, Hidalgo M, Stadler WM, et al: Randomized phase II study of multiple dose levels of CCI-779, a novel mammalian target of rapamycin kinase inhibitor, in patients with advanced refractory renal cell carcinoma. J Clin Oncol 2004;22:909-918. 
138 Davis NB, Taber DA, Ansari RH, et al: Phase II trial of PS-341 in patients with renal cell cancer: a University of Chicago phase II consortium study. J Clin Oncol 2004;22:115-119.

139 Neckers L: Hsp90 inhibitors as novel cancer chemotherapeutic agents. Trends Mol Med 2002;8(suppl):55-61.

140 Kim MS, Kwon HJ, Lee YM, et al: Histone deacetylases induce angiogenesis by negative regulation of tumor suppressor genes. Nat Med 2001;7:437-443.

141 Rapisarda A, Uranchimeg B, Sordet O, et al: Topoisomerase I-mediated inhibition of hypoxia-inducible factor 1 : mechanism and therapeutic implications. Cancer Res 2004; 64:1475-1482.

142 Welsh S, Williams R, Kirkpatrick L, et al: Antitumor activity and pharmacodynamic properties of PX-478, an inhibitor of hypoxia-inducible factor-1alpha. Mol Cancer Ther 2004;3:233-244.

143 Mabjeesh NJ, Escuin D, LaVallee TM, et al: 2ME2 inhibits tumor growth and angiogenesis by disrupting microtubules and dysregulating HIF. Cancer Cell 2003;3: 363-375.
144 Ratain MJ, Flaherty KT, Stadler WM, et al: Preliminary antitumor activity of BAY 43 9006 in metastatic renal cell carcinoma and other advanced refractory solid tumors in a phase II randomized discontinuation trial (RDT). Proc Am Soc Clin Oncol 2004;23: 381.

145 Yang JC, Haworth L, Sherry RM, et al: A randomized trial of bevacizumab, an antivascular endothelial growth factor antibody, for metastatic renal cancer. $\mathrm{N}$ Engl J Med 2003;349:427-434.

146 Motzer RJ, Amato R, Todd M, et al: Phase II trial of antiepidermal growth factor receptor antibody C225 in patients with advanced renal cell carcinoma. Invest New Drugs 2003;21:99-101.

147 Drucker BJ, Schwartz L, Marion S, et al Phase II trial of ZD (Iressa), an EGF inhibitor, in patients with advanced renal cell carcinoma. Proc Am Soc Clin Oncol 2002;21: 181.

148 Ciardiello F, Caputo R, Damiano V, et al: Antitumor effects of ZD6474, a small molecule vascular endothelial growth factor receptor tyrosine kinase inhibitor, with additional activity against epidermal growth factor receptor tyrosine kinase. Clin Cancer Res 2003;9:1546-1556.
149 Motzer RJ, Michaelson MD, Redman BG et al: Activity of SU11248, a multitargeted inhibitor of vascular endothelial growth factor receptor and platelet-derived growth factor receptor, in patients with metastatic renal cell carcinoma. J Clin Oncol 2006;1; 24:16-24.

150 Bartlett JB, Michael A, Clarke IA, et al: Phase I study to determine the safety, tolerability and immunostimulatory activity of thalidomide analogue CC-5013 in patients with metastatic malignant melanoma and other advanced cancers. Br J Cancer 2004; 90:955-961.

151 Bleumer I, Knuth A, Oosterwijk E, et al: A phase II trial of chimeric monoclonal antibody G250 for advanced renal cell carcinoma patients. Br J Cancer 2004;90:985-990.

152 Atkins M, Regan M, McDermott D, et al: Carbonic anhydrase IX expression predicts outcome of interleukin 2 therapy for renal cancer. Clin Cancer Res 2005;15:36013603.

153 Linehan WM, Vasselli J, Srinivasan R, et al: Genetic basis of cancer of the kidney disease-specific approaches to therapy. Clin Cancer Res 2004;10(suppl):6282-6289. 